\title{
Management of early blight of potato using bio control agents and plant extracts
}

\author{
Sahar Murmu ${ }^{1}$, S. Dey ${ }^{1}$ and A. Chakraborty ${ }^{2}$ \\ ${ }^{1}$ Department of Plant Pathology, Bidhan Chandra Krishi Viswavidyalaya, Mohanpur, Nadia- 741252 (West \\ Bengal), INDIA \\ ${ }^{2}$ AICRP on Potato, Directorate of Research, Bidhan Chandra Krishi Viswavidyalaya, Kalyani, Nadia- 741235, \\ (West Bengal), INDIA \\ *Corresponding author. E-mail: saharmurmu@gmail.com
}

Received: March 21, 2015; Revised received: September 3, 2015; Accepted: October 25, 2015

\begin{abstract}
The early blight of potato is mainly controlled by using chemical fungicides but chemical fungicides have got some adverse effect on environment as well as human beings. Keeping this in mind an experiment was conducted to test the efficacy of four plant extracts (tea, garlic, onion and neem leaf extract) and four bio-control agents (Trichoderma viride, Pseudomonas fluorescence, Streptomyces graseoviridis and Bacillus substilis) in controlling early blight of potato under field and in in vitro condition. These antifungal compounds were applied 3 times at 7 days interval after first appearance of the disease in the field. Among the bio control agents $T$. viride was found highly effective in per cent disease reduction $(52.39 \%)$ of disease over control treatment. The tuber yield $(25.51 \mathrm{t} / \mathrm{ha}$.) was also highest in this treatment compared to control treatment (19.53 t/ha). This was followed by treatment $\mathrm{T}_{2}$ i.e. $P$. fluorescens where per cent incidence and intensity of disease were $(65.00 \%)$ and $(19.10 \%)$ respectively with $38.97 \%$ reduction of disease over control with tuber yield $23.65 \mathrm{t} / \mathrm{ha}$. It was followed by $\mathrm{S}$. graseoviridis where per cent incidence and intensity of disease were $(68.00 \%)$ and $(22.90 \%)$ respectively with $26.30 \%$ reduction of disease over control with tuber yield $21.07 \mathrm{t} / \mathrm{ha}$. Among plant extracts, only neem leaf extract exhibited per cent reduction of disease $(33.18 \%)$ over control treatment in field condition and inhibition of radial growth $(59.85 \%)$ and spore germination $(81.95 \%)$ in in vitro condition. Therefore both $T$. viride and neem can be used for managing the early blight of potato.
\end{abstract}

Keywords: Bio control agents, Early blight, management, Potato

\section{INTRODUCTION}

The potato (Solanum tuberosum) is one of the most important vegetable crops in the world, belonging to the family solanaceae and is an important starchy food crop in both sub-tropical and temperate regions. Even in tropical regions it is widely grown during winter season. Potato ( $S$. tuberosum) is a native of South America (Hijmans and Spooner, 2001). In India the potato has been cultivated since its introduction in the early part of the $17^{\text {th }}$ century. In India potato is grown in almost all the states under diverse climatic conditions except Kerala and $82 \%$ of potatoes are grown in plains during the short winter days from October to March. Potato is the most popular crop in West Bengal next to cereals (Chakraborty, 2012).

Potato plants are subjected to attack by numerous diseases wherever the crop is grown. Among them, early blight of potato caused by Alternaria solani (Ellis and Martin) Jones and Grout is of major cause of concern in potato production at present. The disease causes losses to crop productivity in the field and to tuber quality in storage. Average annual yield loss of potato due to this disease was approximately $75 \%$ of the total production depending upon the nature of the disease, weather condition and type of variety grown (Dey and Chakraborty, 2012).

The wide and indiscriminate use of chemical fungicides has been the cause of development of resistance among plant pathogens, leading to the occurrence of serious diseases. Due to this, there is an increasing interest to obtain alternative antimicrobial agents (biocontrol agents) and plant extracts for using in plant disease control systems. Plant products of recognized antimicrobial spectrum could appear in food conservation systems as main antimicrobial compounds or as adjuvant to improve the action of other antimicrobial compounds (Kaur and Arora, 1999).The development of such disease resistance to the pathogens and problems of environmental pollution due to excessive reliance on pesticides are the major causes today. Therefore, to avoid or minimize these problems, experiments have been conducted on management of early blight of potato by using the natural products such as medicinal plant extracts and bio-control agents during 2012-2013 crop seasons. The objectives of present investigations were to evaluate the efficacy of selected bio control 
agents and plant extracts in controlling the early blight disease of potato in field conditions as well as in in vitro condition by using poisoned food technique and spore germination inhibition technique.

\section{MATERIALS AND METHODS}

To study the management response against early blight disease of potato by bio control agents and plant extracts, the variety Kufri Jawahar was used. The experiment was conducted during the Rabi season at Adisaptagram Block Seed Farm, Hooghly, West Bengal during 2012-2013 crop season. Potato was sown on $4^{\text {th }}$ December 2012. The size of the each plot for management trial with bio-control agents and plant extracts was $3 \mathrm{~m} \times 2 \mathrm{~m}$.The field experiment for each factor was laid out in randomised block design (RBD) and there was 4 treatments with 4 replications in each of bio control agents and plant extracts respectively. The chemical fertilizers, N, $\mathrm{P}_{2} \mathrm{O}_{5}$ and $\mathrm{K}_{2} \mathrm{O}$ was applied @ $200 \mathrm{~kg} / \mathrm{ha}, 150 \mathrm{~kg} / \mathrm{ha}$ and $150 \mathrm{~kg} / \mathrm{ha}$ respectively. The $50 \%$ of nitrogen and full dose of $\mathrm{P}_{2} \mathrm{O}_{5}$ and $\mathrm{K}_{2} \mathrm{O}$ were applied during planting and rest $50 \%$ nitrogen was applied as top dressing during earthing up.

The percent disease incidence and intensity was recorded at 7 days interval after first appearance of the disease. Bio control agents and plant extracts were sprayed after taking each observation for percent disease incidence and intensity with their recommended dose such as Trichoderma viride, Bacillus subtilis, Pseudomonas fluorescens, Streptomyces graseoviridis (a) $4 \mathrm{gm} / \mathrm{lit}$ of water, and plant extracts- tea, neem, garlic and onion extracts@2ml/lit of water. For percent disease incidence, first total no. of plants (healthy + infected plants) and then total no. of infected plants in each plot were recorded and the percent disease incidence was calculated by the following formula:

$$
\text { Disease Incidence }(\%)=\frac{\text { No. of Plants Infected }}{\text { No. of Plants Observed }} \times 100
$$

The intensity percent was recorded following descriptive (0-5) scale which is described in table no. 1.

For the study of disease intensity 17 plants per plot was randomly selected and 1 upper leaf, 1 middle leaf and 1 lower leaf of each plant was selected for recording data of PDI using above mentioned rating scale and percent disease index (PDI) or disease intensity percent for each plot was calculated using following formula-

$$
\mathrm{PDI}=\frac{\text { Sum of all numerical ratings }}{\text { Total no of compound leaves observed } \times \text { Maximum ratings }} \times 100
$$

Simultaneously, in vitro management practice was carried out using two methods namely spore germination inhibition technique and poisoned food technique. Therefore the pathogen $A$. Solani was isolated from naturally infected leaf of potato using PDA at $28^{\circ} \mathrm{c}$. In case of spore germination inhibition technique, the per cent inhibition of spore germination was calculated by using following formula given by Vincent (1947).

$$
\text { Inhibition } \%=\frac{C-T}{C} \times 100
$$

Where, $\mathrm{C}=$ Number of germinated spores in control $\mathrm{T}=$ Number of germinated spores in treatment.

In case of poisoned food technique (Falck, 1907) the inhibitory activity of each treatment was expressed as the percent growth inhibition which was calculated using the following formula (Pandey et al., 1982):

$$
\text { Growth inhibition } \%=\frac{D C-D T}{D C} \times 100
$$

Where, $\mathrm{DC}=$ Diameter of control and DT $=$ diameter of fungal colony with treatment.

\section{RESULTS AND DISCUSSION}

The results of the experiment under field condition as well as in vitro condition regarding in management of early blight of potato caused by $A$. solani were presented here. Management trials of the disease under field condition as well as in vitro condition were carried out with four bio control agents and four plant extracts.

Management studies against early blight disease of potato through different bio-control agents under field condition: The results presented in table 2 reveals that the bio control agent $T$. viride $\left(\mathrm{T}_{1}\right)$ exhibited best results in terms of per cent incidence $(61.50 \%)$ and intensity $(14.90 \%)$ of the disease compared to control treatment $\left(\mathrm{T}_{5}\right)$ where per cent incidence and intensity of the disease were $(92.39 \%)$ and $(31.30 \%)$, respectively. The per cent reduction of the disease was $52.39 \%$ over control treatment $\left(\mathrm{T}_{5}\right)$. The tuber yield $(25.51 \mathrm{t} / \mathrm{ha}$.) was highest in comparison to all other treatments. This was followed by treatment $\mathrm{T}_{2}$ i.e. $P$. fluorescens where per cent incidence and intensity of disease were $(65.00 \%)$ and $(19.10 \%)$ respectively with $38.97 \%$ reduction of disease over control with total tuber yield 23.65 t/ha. Among all the bio control agents tested the efficacy of $B$. subtilis was least in terms of per cent incidence $(72.50 \%)$ and intensity $(24.75 \%)$ of the disease. The total tuber yield was also less i.e. $20.23 \mathrm{t} / \mathrm{ha}$.

These findings are also in agreement with Yadav and Pathak (2011) who observed that T.Viride@0.5\% was efficacious in controlling early blight of potato.

Management studies of early blight of potato through different plant extracts: Some plant extracts were tested to observe their efficacy on management of

Table 1. Rating scale (0-5) for measuring disease intensity of early blight of potato.

\begin{tabular}{llc}
\hline Description & & Rating \\
\hline Free from infection (no & visible & 0 \\
symptoms). & \\
$1-10 \%$ leaf area damaged. & 1 \\
$10.1-20 \%$ leaf area damaged. & 2 \\
$20.1-50 \%$ leaf area damaged. & 3 \\
$50.1-75 \%$ leaf area damaged. & 4 \\
Above 75\% leaf area damaged. & 5 \\
\hline
\end{tabular}



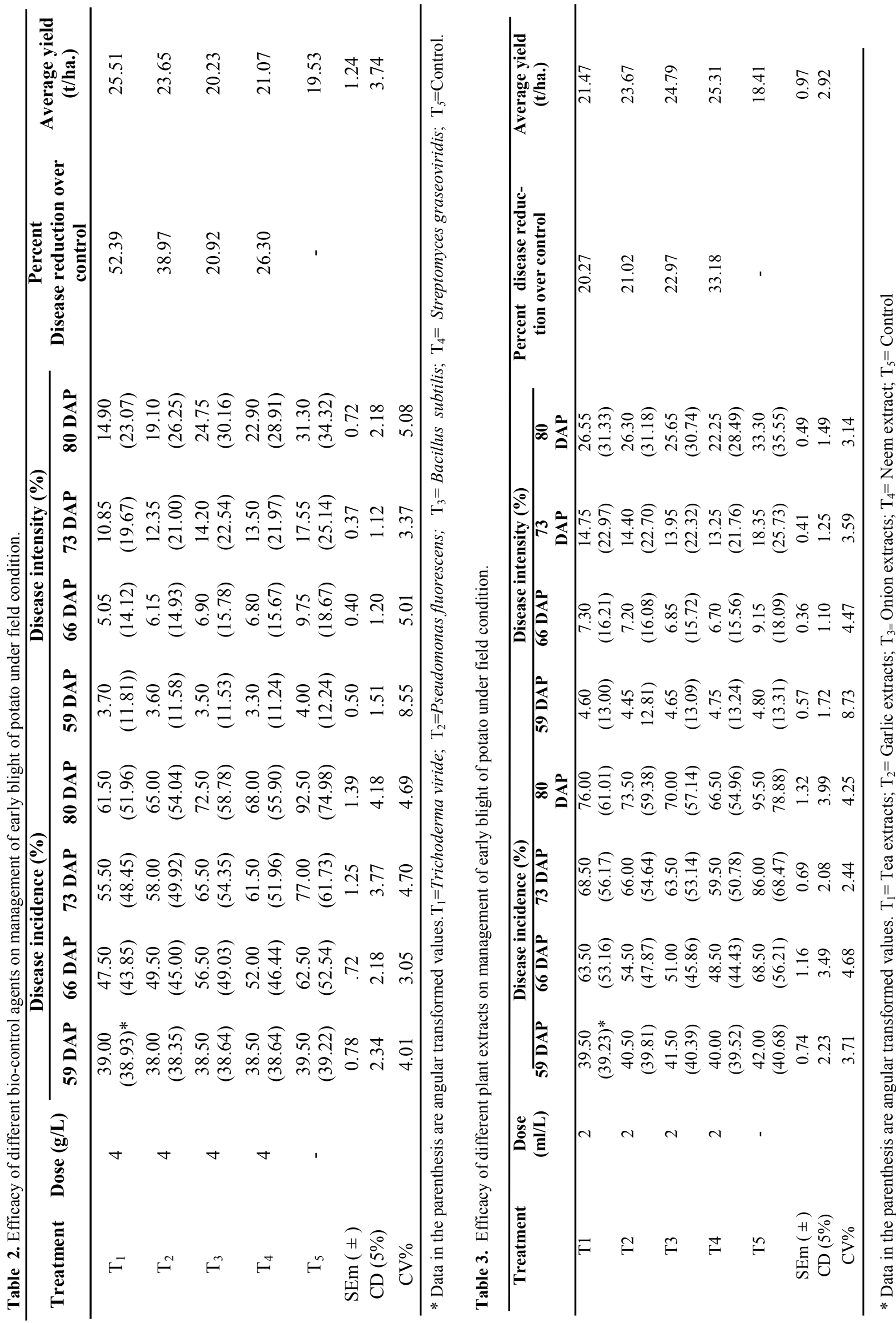
Table 4. Efficacy of plant extracts on growth inhibition of $A$. solani in in vitro condition.

\begin{tabular}{|c|c|c|c|c|c|c|c|}
\hline \multirow[t]{2}{*}{ Treatment } & \multirow{2}{*}{$\begin{array}{l}\text { Conc. } \\
\text { (ppm) }\end{array}$} & \multicolumn{5}{|c|}{ Colony growth at 24 hours interval (cm) } & \multirow{2}{*}{$\begin{array}{l}\text { Growth inhibition } \\
\text { over control }(\%)\end{array}$} \\
\hline & & (48 hrs) & (72 hrs) & (96 hrs) & (120 hrs) & (144 hrs) & \\
\hline $\mathrm{T}_{1}:$ Garlic & 2000 & 3.87 & 4.37 & 5.10 & 6.77 & 7.97 & 5.90 \\
\hline $\mathrm{T}_{2}$ : Garlic & 4000 & 3.63 & 4.27 & 4.73 & 6.57 & 7.73 & 8.73 \\
\hline $\mathrm{T}_{3}$ : Onion & 2000 & 3.70 & 3.90 & 4.27 & 6.30 & 7.53 & 11.09 \\
\hline $\mathrm{T}_{4}$ : Onion & 4000 & 2.77 & 3.33 & 4.37 & 5.67 & 7.00 & 17.35 \\
\hline $\mathrm{T}_{5}:$ Neem & 50 & 1.60 & 2.03 & 2.53 & 3.40 & 4.03 & 52.42 \\
\hline $\mathrm{T}_{6}:$ Neem & 100 & 1.10 & 1.67 & 2.13 & 2.40 & 3.40 & 59.85 \\
\hline $\mathrm{T}_{7}:$ Tea & 2000 & 3.03 & 3.57 & 4.53 & 6.10 & 7.50 & 11.45 \\
\hline $\mathrm{T}_{8}:$ Tea & 4000 & 2.17 & 2.77 & 3.50 & 4.40 & 6.53 & 22.90 \\
\hline $\mathrm{T}_{9}:$ Control & - & 4.37 & 4.87 & 5.60 & 7.27 & 8.47 & - \\
\hline \multicolumn{2}{|c|}{$\operatorname{SEm}( \pm)$} & 0.05 & 0.06 & 0.13 & 0.17 & 0.11 & \\
\hline \multicolumn{2}{|c|}{$\mathrm{CD}(\overline{5 \%})$} & 0.16 & 0.18 & 0.40 & 0.50 & 0.33 & \\
\hline
\end{tabular}

Table 5. Efficacy of plant extracts on inhibition conidial germination of A.solani in in vitro condition.

\begin{tabular}{|c|c|c|c|c|}
\hline \multirow[b]{2}{*}{ Treatment } & \multirow[t]{2}{*}{ Conc. (ppm) } & \multicolumn{2}{|c|}{ Spore germination $\%$ at 24 hours interval } & \multirow{2}{*}{$\begin{array}{c}\text { Spore germination } \\
\text { inhibition over } \\
\text { control }(\%)\end{array}$} \\
\hline & & (24 hrs) & (48 hrs) & \\
\hline $\mathrm{T}_{1}$ : Garlic & 2000 & $96.22(79.58)^{*}$ & $98.33(84.26)$ & 0.34 \\
\hline $\mathrm{T}_{2}$ : Garlic & 4000 & $94.12(76.60)$ & $98.00(82.97)$ & 0.67 \\
\hline $\mathrm{T}_{3}$ : Onion & 2000 & $92.13(74.30)$ & $96.87(80.71)$ & 1.84 \\
\hline $\mathrm{T}_{4}$ : Onion & 4000 & $86.52(68.89)$ & $95.11(78.05)$ & 3.60 \\
\hline $\mathrm{T}_{5}:$ Neem & 50 & $30.95(34.09)$ & $35.74(37.00)$ & 63.77 \\
\hline $\mathrm{T}_{6}:$ Neem & 100 & $14.90(23.07)$ & $17.81(25.26)$ & 81.94 \\
\hline $\mathrm{T}_{7}:$ Tea & 2000 & $77.45(62.00)$ & $82.77(65.89)$ & 16.11 \\
\hline $\mathrm{T}_{8}:$ Tea & 4000 & $45.66(42.80)$ & $48.75(44.57)$ & 50.59 \\
\hline $\mathrm{T}_{9}:$ Control & - & $98.49(84.33)$ & $98.67(84.95)$ & - \\
\hline $\operatorname{SEm}( \pm)$ & & 0.78 & 1.14 & \\
\hline $\mathrm{CD}(5 \%)$ & & 2.33 & 3.39 & \\
\hline
\end{tabular}

* Data in the parenthesis are angular transformed values.

early blight disease. Though the efficacy was not at par with chemical management but considering the human health hazard and huge cost involvement in chemical management, the disease management with plant extracts has got their relevance in modern day agriculture. It is indicated from the result presented in table (3) that neem extract@2 ml/lit. exhibited the best result in terms of per cent disease incidence $(66.50 \%)$ and intensity $(22.25 \%)$ as compared to control treat$\operatorname{ment}\left(\mathrm{T}_{5}\right)$ at $80 \mathrm{DAP}$ where per cent disease incidence and intensity were $95.50 \%$ and $33.30 \%$ respectively. The per cent reduction of disease over control was $33.18 \%$ and total tuber yield was also highest i.e.25.31 $\mathrm{t} /$ ha compared to control treatment where only $18.41 \mathrm{t} /$ ha was recorded. The next best result was obtained with onion extract which@ 2 ml/L exhibited 22.97\% reduction of disease over control. In comparison to other treatments tea extract exhibited lesser effect, where $76.00 \%$ disease incidence and $26.55 \%$ intensity was recorded. Naturally the total tuber yield $(21.47 \mathrm{t} /$ ha.) was also less as compared to other treatments.

These findings are also in agreement with Chaudhary and Chaudhary (2003) who reported the efficacy of leaf extracts of Eucalyptus globulus, Datura stramonium, Solanum xanthocarpum, Azadirachta indica, Lantana camara, Ricinus communis and Lawsonia inermis; bulb extracts of Allium sativum and Allium cepa and rhizome extracts of Zingiber officinale in controlling Alternaria solani causing early blight in potato in in vitro condition.

In vitro efficacy of plant extracts on inhibition of mycelial growth of $\boldsymbol{A}$. solani: Four plant extracts were tested for their efficacy against inhibition of radial growth of $A$. solani through bio-assay technique. It is evident from results presented in table (4) that highest per cent growth inhibition i.e. $59.85 \%$ and $52.42 \%$ over control was achieved by neem extract ( $A$. indica) at 100 and $50 \mathrm{ppm}$ concentration respectively. In case of other plant extracts like tea (2000 and $4000 \mathrm{ppm})$ and onion (2000 and $4000 \mathrm{ppm}$ ) 11.45\%, 22.90\%, and $11.09 \%$ and $17.35 \%$ growth inhibition respectively over control were achieved. But garlic extracts had least effect i.e. $5.90 \%$ and $8.73 \%$ over control at 2000 and 4000 ppm respectively. 
The above findings are also in line with those of Neeraj and Shilpi (2010), who studied that the neem leaf extract was highly effectine in inhibition of the radial growth of $A$. solani.

Maya and Thippanna (2013) were of opinion that leaf and seed extracts of $A$. indica recorded maximum mycelial growth inhibition of $A$. Solani.

Efficacy of plant extracts on inhibition conidial germination of $A$. solani in in vitro condition: It is evident from the table (5) that except neem ( $A$. indica), no other plant extracts had any marked effect on conidial germination. Neem extract at 50 and 100 ppm concentration exhibited $63.77 \%$ and $81.94 \%$ inhibition of conidial germination, respectively over control. Tea extract at $4000 \mathrm{ppm}$ concentration exhibited $50.59 \%$ inhibition of conidial germination but at $2000 \mathrm{ppm}$ concentration per cent inhibition of conidial germination was only $16.11 \%$ over control. But in case of onion and garlic negligible per cent inhibition of conidial germination was observed at 2000 and 4000 ppm concentration over control.

\section{Conclusion}

It was concluded that $T$. viride and neem extract can be used for controlling of early blight of potato and in the contest of adverse effect of chemical fungicides the use of bio control agents and plant extracts are of great significance in present day agriculture.

\section{REFERENCES}

Chakraborty, A. (2012). Prevalence of diseases of potato in Indo-Gangetic plains of West Bengal. J. Mycopathol. Res., 50 (1):117-119.

Dey, S. and chakraborty, A. (2012). Varietal reaction against early blight of potato in plains of West Bengal. J. Crop Weed., 8 (1): 181-183.

Hijmans, R.J. and Spooner, D.M. (2001). "Geographic distribution of wild potato species". Am. J. Bot., (Botanical Society of America) 88 (11): 2101-12.

Kaur J., Arora D. (1999). Antimicrobial activities of species. Int. J. Antimicrob. Agents, 12: 257-262.

Maya, C. and Thippanna, M. (2013). In vitro evaluation of ethano-botanically important plant extracts against early blight disease (Alternaria Solani) of tomato. G.J.B.B. 2 (2): 248-252.

Neeraj and Shilpi Verma (2010). Alternaria diseases of Vegetable Crops and New Approaches for its Control. Asian J. Exp. Biol., 1 (3): 681-692.

Pandey, D. K., Tripathi, N.N., Tripathi, R.O. and Dixit, S.N. (1982). Fungitoxic and phyototoxic properties of essential oil of Phylissauvolensis. Pfkrankh Pfschuz, 89: 334346.

Yadav, R. and Pathak, S.P. (2011). Management of early blight of potato through fungicides and botanicals and bio agents. Plant Arch., 11(2):1143-1145.

Vincent, J.M. (1947). Distortion of fungal hyphae in the presence of certain inhibitors. Nature, 159: 239-241. 